\title{
Editorial
}

\section{Top ten in Journal of Biology in 2009: stem cells, influenza, pit bulls, Darwin, and more}

\author{
Miranda Robertson
}

This is a more or less frivolous look at the top ten most accessed articles - of any kind - published in Journal of Biology this year. Frivolous, because the validity of any conclusions drawn from this statistic is undermined by many considerations. The number of times an article is accessed does not measure how many people actually read it, nor, for most articles, is it any indication of how much it will be cited (itself an imperfect measure of importance): it is most likely to reflect what people think they want to read about.

Even then, there is the problem that more recently published articles have had less time to accrue accesses; although by far the highest access rates occur in the first three or four weeks after publication, most in the first two, so that in practice, given the actual numbers, even correcting for these discrepancies would make no difference to the top five, though it might affect the last two or three on the list.

Indeed, the two most accessed articles, an Opinion from Arthur Lander on the stem cell concept [1] and a Q\&A from Stephen Turner, Lorena Brown, Peter Doherty and Anne Kelso on what we have learned about the influenza A ( $\mathrm{H} 1 \mathrm{~N} 1)$ pandemic virus [2], were both published relatively recently, in September. Clearly a major factor is topicality: the earlier influenza A (H1N1) Q\&A from Doherty and Turner [3] is also on the list, at seventh. Another factor, probably, is the whiff of controversy - Lander's article asks whether the stem cell concept is holding us back - and an Opinion from Alexey Khodjakov and Conly Rieder, provocatively entitled 'The nature of cell cycle checkpoints: facts and fallacies' [4], published more recently still, is ninth.

The third most accessed of the top ten combines a topic of perennial interest - in all senses of that word - with probably the most arresting title we have published this year: 'Are we training pit bulls to review our manuscripts?' [5], under which Virginia Walbot not only answers the question (yes), but proposes a taming protocol. The pit-bull reviewer is the problem that we for our part have proposed to address with our experimental re-review opt-out policy - see 'What are journals for?' [6], at eighth - an experiment whose results I should have liked to report had the $n$ so far been large enough to raise any discussion above the anecdotal. I do however feel able with reasonable confidence to reject one of the most important objections to the policy, which is that if authors are allowed to opt out of re-review of their revised manuscripts reviewers may refuse to referee them. We have had no refusals - although it is impossible to say whether this means reviewers are content with the policy, or simply don't read beyond the first paragraph of the request to where the policy is explained. Probably both.

What else? Fifth most accessed, and again both topical and provocative, is Jonathan Howard's Opinion on why Darwin didn't discover Mendel's laws [7]; and the two research papers in the top ten, Chan et al. on conservation of gene expression in vertebrate tissues [8] and Puigbo et al. on the tree of life [9] both reflect the current preoccupation with the potential of genomic analysis for resolving profound evolutionary issues - in one case, the longstanding issue of the path to our remote ancestry; in the other, the more recent question of how exactly the evolution of form and function reflects the evolution of gene regulation.

The tenth most accessed article is a Minireview by Lucy Dalton-Griffin and Paul Kellam on infectious causes of cancer [10]. There seems little question that the articles that most reliably interest the broadest spectrum of readers without any special topical, controversial, political or provocative appeal, are those on biology with direct medical relevance. In 2010, we shall be recognizing this interest with a series of articles on biology addressed to clinical issues. Ring in the new.

\section{Miranda Robertson, Editor \\ editorial@jbiol.com}

\section{References}

1. Lander A: The 'stem cell concept': is it holding us back? $J$ Biol 2009, 8:70.

2. Turner SJ, Brown LE, Doherty PC, Kelso A: Q\&A: What have we found out about the influenza A (H1N1) 2009 pandemic virus? J Biol 2009, 8:69.

3. Doherty PC, Turner SJ: Q\&A: What do we know about influenza and what can we do about it? J Biol 2009, 8:46.

4. Khodjakov A, Rieder CL: The nature of cell cycle checkpoints: facts and fallacies. J Biol 2009, 8:88.

5. Walbot $\mathrm{V}$ : Are we training pit bulls to review our manuscripts? J Biol 2009, 8:24. 
6. Robertson M: What are journals for? J Biol 2009, 8:1.

7. Howard JC: Why didn't Darwin discover Mendel's laws? J Biol 2009, 8:33.

8. Chan ET, Quon GT, Chua G, Babam T, Trochesset M, Zirngibl R, Aubin J, Ratcliffe M, Wilde W, Brudno M, Morris QD, Hughes TR: Conservation of gene expression in vertebrate tissues. J Biol 2009, 8:33.

9. Puigbo P, Wolf YI, Koonin EV: Search for a 'Tree of Life' in the thicket of the phylogenetic forest. J Biol 2009, 8:59.
10. Dalton-Griffin L, Kellam P: Infectious causes of cancer and their detection. J Biol 2009, 8:67.

Published: 31 December 2009

doi:10.1186/jbiol210

(c) 2009 BioMed Central Ltd 